Revue de l'Institut des langues et cultures

d'Europe, Amérique, Afrique, Asie et Australie

42 | 2021

Le politiquement correct : tabous, normes, transgressions

\title{
Les termes et expressions de l'économie collaborative en anglais : une étude diachronique
}

The Terms and Expressions that Refer to the Collaborative Economy in English: A Diachronic Study

\section{Caroline Benedetto}

\section{OpenEdition}

Journals

Édition électronique

URL : http://journals.openedition.org/ilcea/11957

DOI : 10.4000/ilcea. 11957

ISSN : 2101-0609

Éditeur

UGA Éditions/Université Grenoble Alpes

Édition imprimée

ISBN : 978-2-37747-251-2

ISSN : 1639-6073

\section{Référence électronique}

Caroline Benedetto, « Les termes et expressions de l'économie collaborative en anglais : une étude diachronique », ILCEA [En ligne], 42 | 2021, mis en ligne le 31 janvier 2021, consulté le 01 février 2021 URL : http://journals.openedition.org/ilcea/11957 ; DOI : https://doi.org/10.4000/ilcea.11957

Ce document a été généré automatiquement le 1 février 2021.

(C) ILCEA 


\title{
Les termes et expressions de l'économie collaborative en anglais : une étude diachronique
}

The Terms and Expressions that Refer to the Collaborative Economy in English:

\author{
A Diachronic Study
}

Caroline Benedetto

\section{Introduction}

1 L'objet de cet article, qui se situe dans le cadre des études d'anglais de spécialité, est d'étudier quelques-uns des termes et expressions de l'économie collaborative qui se sont diffusés dans la presse anglophone, à partir d'un corpus d'articles publiés entre 2012 et 2019. Il s'inscrit dans la continuité de travaux de recherche précédents, dans lesquels nous avons envisagé les termes comme une voie d'accès privilégiée à la culture des milieux spécialisés (Benedetto, 2019a, 2019b).

2 L'économie collaborative comprend des pratiques de consommation très diverses entre particuliers comme la vente, la location, le partage ou l'échange de biens, de services ou de connaissances ${ }^{1}$. Galvanisées par l'essor des technologies numériques et par le développement de communautés dont les membres font affaire entre eux sur des places de marché virtuelles, ces pratiques ont connu un essor fulgurant après la grande crise financière de 2008, d'abord aux États-Unis, puis dans le reste du monde. Elles sont rapidement devenues incontournables dans de nombreux secteurs d'activité, allant de l'industrie à la finance, en passant par les transports, l'éducation, le tourisme et les services à la personne.

3 Traditionnellement, les partisans de ce nouveau modèle socio-économique vantent la façon dont il transforme les modes de production et de consommation, en les associant aux notions de partage et d'abandon de la propriété au profit de l'usage, pour une société plus durable. En revanche, ses détracteurs lui reprochent, par exemple, de saper 
les standards de protection sociale des travailleurs et de mettre à mal la capacité de l'État à réglementer les marchés. Depuis son apparition, l'économie collaborative fait ainsi l'objet de vives controverses dans la presse anglophone.

4 Nous souhaitons donc nous interroger sur la manière dont la notion d'économie collaborative est abordée dans le discours journalistique. Nous nous demandons si ce traitement a évolué au cours de la dernière décennie, à partir d'une étude en diachronie courte des termes et expressions qui y font référence ${ }^{2}$. Cet angle d'approche a été privilégié car il se montre utile pour éclairer la connaissance des milieux spécialisés qui sont marqués par une évolution rapide des connaissances et des concepts, comme celui de l'économie.

Ce travail doit aussi nous permettre d'étudier le positionnement des formes lexicales du corpus par rapport aux normes linguistiques en vigueur au sein d'une société donnée. Comme nous le démontrons dans la suite de cet article, certains des termes identifiés sont assimilables à des formes de l'« économiquement correct » dans la mesure où ils sont conformes aux aspirations et aux attentes des citoyens. Nous postulons que ces termes sont porteurs d'une certaine vision économique et sociale du monde qu'ils tentent non seulement de légitimer mais, peut-être aussi, de pérenniser et d'internationaliser.

\section{Méthodologie}

\subsection{Choix des expressions clés pour la recherche d'articles de presse}

6 La terminologie de l'économie collaborative étant fortement hétérogène, nous avons restreint notre recherche d'articles de presse aux quatre termes suivants: sharing economy, on-demand economy, gig economy et collaborative economy ${ }^{3}$. Nous les avons sélectionnés à la fois en raison de leur fréquence élevée d'apparition sur internet, attestant de leur circulation dans le discours public sur l'économie, et de leur présence dans les grands dictionnaires anglophones. En outre, d'après une classification établie par Görög (2018: 181), ces quatre termes font partie des 15 désignations les plus répandues sur le web pour désigner le nouveau type d'économie.

7 En dépit de leur récurrence dans le discours médiatique, les autres dénominations répertoriées par Görög dans sa classification n'ont pas été retenues pour notre recherche d'articles, car elles ne recouvraient pas totalement les mêmes concepts que celui de l'économie collaborative.

8 Par exemple, le terme digital economy (économie numérique), dont la définition est étroitement liée à l'utilisation des outils numériques ${ }^{4}$, n'implique pas systématiquement le concours, l'aide ou la participation des membres d'un système en vue de l'élaboration d'une œuvre commune, à la différence des termes collaborative economy et sharing economy, qui mettent l'accent sur le partage et la collaboration entre acteurs, comme nous le verrons dans la suite de cet article.

Nous n'avons pas non plus analysé collaborative consumption, dont le sens nous paraissait trop restreint en adoptant le seul angle de la consommation, sans tenir compte du lien qui unit les formes de socialisation et les modes de production (techniques, économiques et sociaux) à l'œuvre dans le nouveau modèle socio-économique. 


\subsection{Délimitation de la période d'étude}

La période d'étude a été définie par rapport à la diffusion de sharing economy, un terme que nous avons choisi en raison de sa fréquence d'emploi très élevée sur internet ${ }^{5}$.

Pour retracer l'origine de son utilisation et mesurer l'évolution de sa popularité sur la toile, nous avons utilisé Google Trends, un outil mis au point par Google pour connaître la fréquence à laquelle un terme ou une expression a fait l'objet d'une recherche, avec la possibilité de visualiser ces données par région, par langue et par année. À noter que la courbe affichée n'indique pas un nombre de recherches absolu mais une proportion entre 0 et 100 , où 100 représente la quantité maximale de requêtes menées dans la période et le lieu définis. Les graphiques représentés nous ont permis non seulement d'observer les tendances générales de recherche pour le terme sharing economy, mais aussi de voir comment a évolué sa popularité au cours du temps.

Nous avons lancé une recherche du terme anglais, inséré entre guillemets, pour la période 2008-2019. Bien qu'il soit apparu pour la première fois en 2007, il fait l'objet d'un nombre très réduit de recherches de 2008 à 2011, à savoir moins de deux requêtes par mois (fig. 1). Par la suite, on constate que le volume des recherches correspondant à sharing economy augmente progressivement, passant de $5 \%$ en novembre 2012 à $14 \%$ en mai 2013, avant d'atteindre $29 \%$ en mai 2014. Il continue de monter en flèche les années suivantes pour atteindre $92 \%$ en novembre 2015 et $100 \%$ en avril 2016, ce qui montre l'intérêt grandissant des lecteurs de la presse anglophone pour l'économie collaborative.

Figure 1. - Période de diffusion de l'expression the sharing economy.

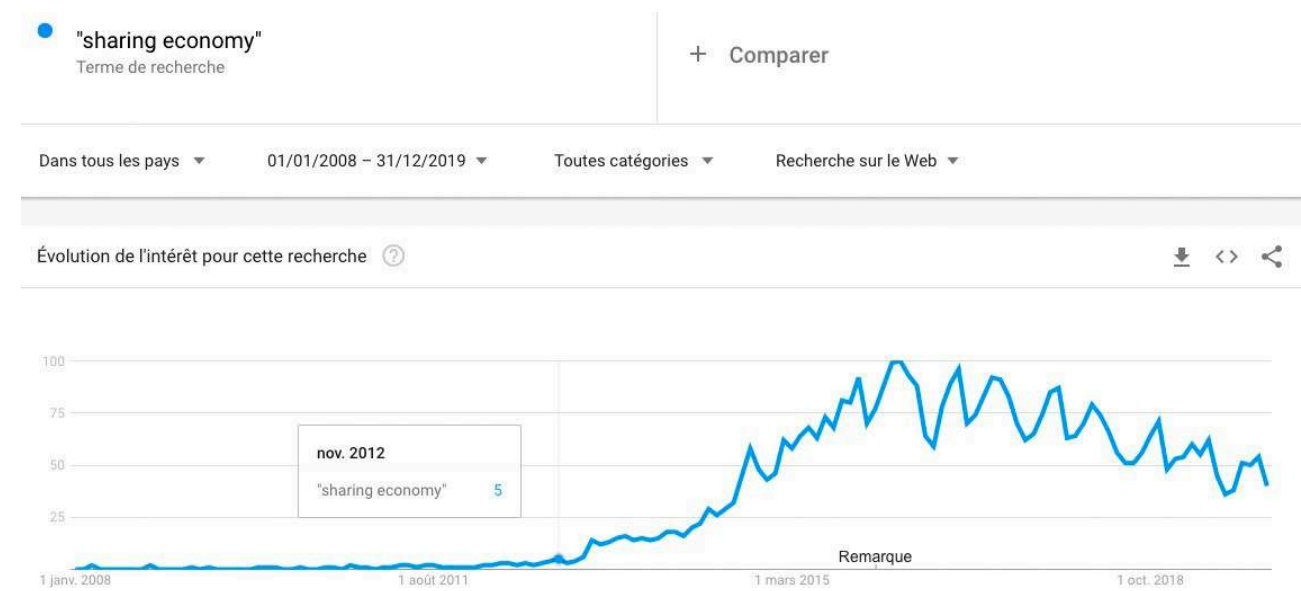

La forte diffusion de sharing economy dans le discours public a été facilitée, semble-t-il, par la démocratisation de l'accès aux nouvelles technologies et par l'essor des plateformes commerciales en ligne comme Uber, Airbnb ou Lyft, qui ont encouragé les formes d'échanges entre particuliers à se développer. En outre, la publication d'ouvrages qui vantent les mérites de l'économie collaborative (Botsman \& Rogers, 2010; Gansky, 2010), ainsi que le lancement de sites web destinés à valoriser les initiatives innovantes qui fourmillent dans ce secteur (comme Shareable et The People Who Share, par exemple), ont probablement aiguisé l'intérêt du grand public pour le sujet. 
14 Toutefois, à partir de l'été 2016, le volume des recherches correspondant à sharing economy diminue de moitié jusqu'en août 2018 (fig. 1). Il passe ainsi de $100 \%$ en avril 2016 à $51 \%$ en août 2018. Cette forte baisse de popularité peut s'expliquer par le fait que d'autres termes plus répandus dans le discours médiatique anglophone, tels que gig economy, ont pris la relève (fig. 2). Ainsi, pour le mois de juillet 2016, le volume des recherches correspondant à ce dernier terme est trois fois plus important que pour sharing economy.

Figure 2. - Comparaison des tendances générales de recherche correspondant aux expressions sharing economy et gig economy en juillet 2016.
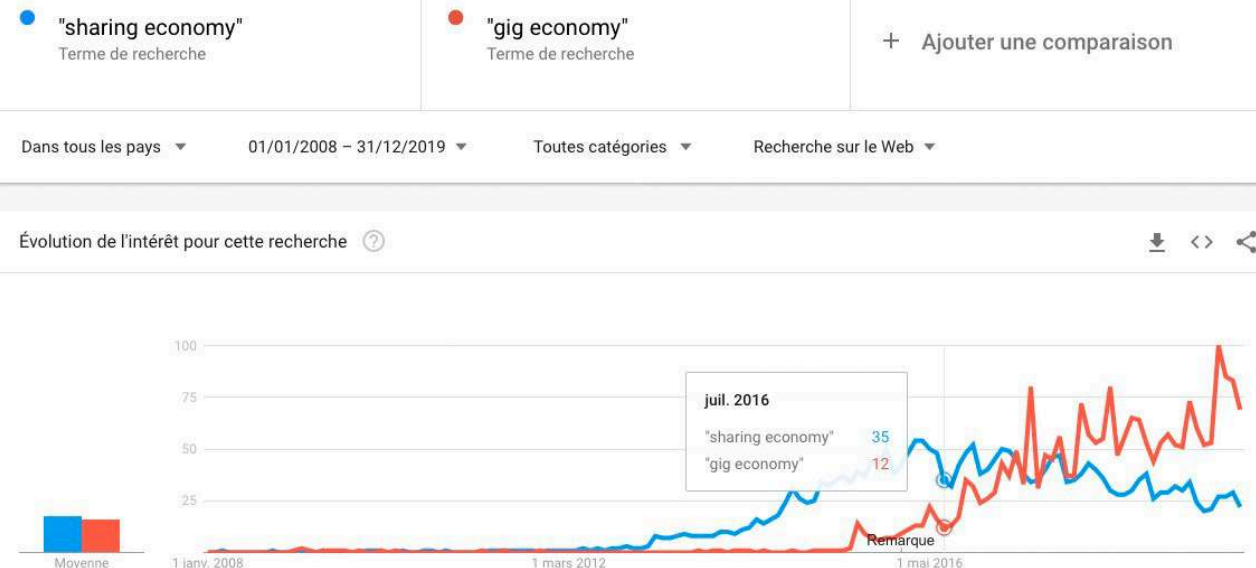

Cette tendance générale se poursuit jusqu'en septembre 2019: une comparaison des recherches portant sur chacun de ces deux termes montre que gig economy est 3,7 fois plus employé dans les requêtes d'internautes que sharing economy (fig. 3). Si, durant cette période, l'économie collaborative est toujours un sujet qui suscite la curiosité des internautes, la popularité des formes lexicales qui servent sa désignation a connu une évolution importante en l'espace de sept ans seulement.

Figure 3. - Comparaison des tendances générales de recherche en septembre 2019.

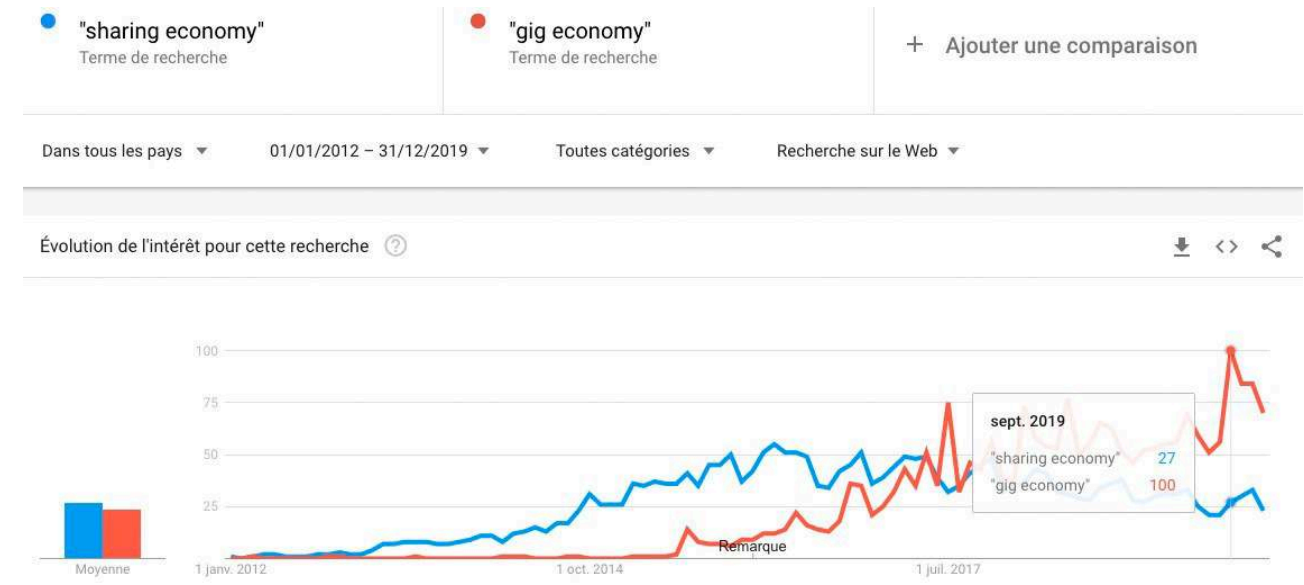

\subsection{Sources du corpus}

Après avoir délimité le contexte temporel de notre étude, nous avons sélectionné 80 articles publiés entre 2012 et 2019 dans des quotidiens généralistes de la presse 
écrite anglophone (The Guardian, The New York Times, TIME, etc.) et dans quelques magazines spécialisés dans le domaine de l'économie (Forbes, The Economist, The Harvard Business Review, etc.). Nous avons retenu dix articles par année, émanant de sources diverses afin de promouvoir une certaine hétérogénéité des points de vue. Seuls les documents qui traitent des manifestations de l'économie collaborative et de son impact dans le monde anglophone ont été intégrés au corpus.

Une lecture attentive des textes nous a permis d'identifier deux catégories de termes et d'expressions. La première comprend des formes linguistiques apparues de 2012 à 2015 pour valoriser les aspects positifs du modèle socio-économique. La seconde est constituée de formes plus critiques, qui ont émergé de 2015 à 2019 : elles permettent aux journalistes non seulement de contester les désignations précédemment employées dans le discours médiatique, mais aussi de mettre au jour certains aspects plus sombres du système économique contemporain.

\section{Les termes et expressions aux connotations valorisantes}

\subsection{Sharing economy}

Le terme sharing economy ${ }^{6}$ se distingue d'emblée de toutes les autres désignations de l'économie collaborative par son orientation communautaire. En particulier, la connotation affective de l'adjectif sharing présente ce type d'économie comme un modèle appelé à dépasser les transactions commerciales sur le web pour développer l'interaction et les contacts sociaux. De façon quelque peu surprenante, donc, l'internet en fait un système centré sur l'humain, un moyen de rencontrer ses voisins et de lutter contre l'individualisme, comme l'illustrent ces propos rapportés de Botsman, une essayiste australienne qui soutient le modèle de l'économie collaborative :

The popularity of sharing suggests something deeper could be going on within society as a whole. Botsman certainly thinks so; she talks of a shift from a "me culture" to a "we culture". The "social self" is on the rise; the side of us that hungers for community and connection. "This is one of the first generations that is really questioning whether big fences make good neighbours. Are we really happy when we keep up with the Joneses, or should we get to know the Joneses?" she asks. (The Guardian, 2012c)

De la même façon, les caractérisations élogieuses qui émanent des partisans de l'économie collaborative (dont les propos sont repris par les journalistes) contribuent à diffuser des représentations positives du modèle socio-économique, comme le montrent ces quelques exemples : « the business of the future » (BBC, 2013a), « a new UN », " an economy that benefits everyone », " app-enabled humanitarianism » (The Financial Times, 2013).

Associé au partage, le terme contribue à valoriser une façon de produire et de consommer qui s'appuie fortement sur le lien social entre utilisateurs, allant jusqu'à nourrir des relations d'entraide et de solidarité. C'est ainsi, par exemple, que la plateforme de location d'hébergement entre particuliers Airbnb a créé le site web Open Homes spécialement pour venir en aide aux réfugiés climatiques ou politiques. Lancée à New York en 2013, à la suite des dégâts provoqués par l'ouragan Sandy, cette initiative a permis aux hôtes inscrits sur la plateforme commerciale en ligne d'offrir l'hospitalité 
aux victimes, sans que l'entreprise ne perçoive aucun frais de service (The New York Times, 2014a).

21 Dans d'autres textes du corpus, l'économie collaborative est décrite comme un moyen de lutter contre la consommation excessive et de préserver l'environnement :

Hyper-consumption combined with an increasing population is draining our finite resources. My lifestyle multiplied was not sustainable. So, I gave up my shopping habit and began to share, swap and borrow, buying only what I need and buying things secondhand - and so sharing the lifecycle of the product. (The Guardian, 2012b)

The expansion of the sharing economy offers a more sustainable alternative to mainstream economics. [...]. In light of an impending energy crisis, a financial system that benefits few at the expense of many, and environmental degradation caused by unchecked, unnecessary consumption, it's clear something has to change. The arrival of a set of systems that prioritise collaboration is most certainly a welcome one. (The Guardian, 2014a)

Enfin, les pratiques d'échange entre particuliers comme le covoiturage et l'hébergement chez l'habitant, par exemple, sont présentées comme économiquement avantageuses pour les citoyens ordinaires, qui peuvent valoriser leur capital dormant en partageant son usage et/ou bénéficier de l'usage d'un produit ou d'un service à moindre coût :

Survey found that $42 \%$ of hosts used Airbnb money for regular living expenses. Another $48 \%$ used the money for extra spending money. Separately 56\% of hosts said they used their Airbnb income for rent or mortgage. It's not surprising considering how expensive real estate is in San Francisco. As a result, Airbnb is enabling people to use an asset that is not being used-their home-and extracting extra value out of it. (Forbes, 2012)

These companies, such as the car-sharing sites Zipcar and Getaround, have several benefits for owners and borrowers. Owners can earn money from an extra room or car that sits idle several hours a day. Borrowers save money. And society benefits from the decreased accumulation of goods that sit idle instead of contributing to the self-storage industry that in the US is worth $\$ 20 b n$ ( $£ 13 b n$ ). (The Guardian, 2012b)

\subsection{Collaborative economy}

23 Moins récurrent dans la presse anglophone que la forme précédente, le terme collaborative economy désigne un ensemble de pratiques sociétales fondées sur la mise en commun des ressources, aussi bien matérielles que humaines, dans la perspective de mieux consommer et de mieux travailler ensemble. Sa mention dans les textes du corpus souligne ainsi avec force la dynamique d'échange et de coopération insufflée par le modèle économique contemporain :

She [US entrepreneur Robin Chase] refers to the new era of collaboration as Peer Inc in which "super- charged individuals" pool their skills to solve mundane and complex problems. Examples include The Amazings, a website which allows the over-60s to share their skills, and Topcoder, where more than 400,000 engineers offer to solve complex coding problems. (BBC, 2012)

24 Cette dynamique profite aux entreprises qui, grâce aux potentialités des nouvelles technologies, bénéficient à la fois d'un accès immédiat aux services des meilleurs travailleurs indépendants disponibles sur le marché et d'une hyperspécialisation de leur main-d'œuvre, ce qui leur permet de gagner en productivité et en compétitivité :

It used to be that companies would gain a competitive edge by bringing more and more people, assets, and resources inside the company in order to reduce transaction costs. The Internet has stripped that advantage away. Now, the smartest companies are using the Internet's ability to facilitate collaboration by leveraging assets, resources, and expertise outside of their sphere of control. (HBR, 2015a) 
Enfin, à l'instar de sharing economy, le terme collaborative economy contribue à mettre en évidence les bienfaits du nouveau type d'économie pour l'écologie et l'environnement :

It has been heralded as the "new industrial revolution", and a solution to the conundrum of a world with a growing population but rapidly diminishing resources. This "collaborative economy" is estimated to be worth more than $\$ 26 \mathrm{bn}$ (£16.5bn). (BBC, 2013b)

For Chase, the shift to a collaborative economy is not about moving with the times and embracing fashionable tech disruption. The threat of climate change means this is a question of life and death, she writes. "We need Peers Inc because sharing of physical assets requires the least amount of stuff to sustain the greatest number of people." (The Financial Times, 2015)

\subsection{On-demand economy}

À son tour, l'emploi du terme on-demand economy associe des représentations positives au modèle contemporain en soulignant l'accessibilité et la commodité des biens et services qui, commandés à partir d'applications mobiles, sont promptement alloués aux particuliers :

No doubt these services are helpful; in all three instances, they were lifesavers. This emerging on-demand economy, made up of a wave of mobile applications and services, is certainly convenient. It is intended to deliver almost anything you need or want with the flick of a finger, if you have a smartphone and the cash to spare. A game changer? Definitely. (The New York Times, 2012)

Yet this on-demand economy goes much wider than the occasional luxury. Click on Medicast's app, and a doctor will be knocking on your door within two hours. Want a lawyer or a consultant? Axiom will supply the former, Eden McCallum the latter. Other companies offer prizes to freelances to solve R\&D problems or to come up with advertising ideas. (The Economist, 2014)

Cette " économie à la demande ${ }^{7}$ » est également décrite comme une source d'autonomie pour les travailleurs qui sont mis en relation avec leurs employeurs en seulement quelques clics sur des plateformes virtuelles, et qui peuvent ainsi travailler quand ils le souhaitent :

That freedom is what attracts many people to the on-demand economy. "It's literally the easiest job I've ever done for the most amount of money," says Christopher Gutierrez, who drives for Lyft, Uber's main U.S. rival, in Chicago. "I always tell people, 'I don't have a boss. I have an app."' (Time, 2015)

\subsection{Peer-to-peer economy}

Souvent abrégée P2P economy dans la presse anglophone ${ }^{8}$, la notion d'économie du pair à pair ${ }^{9}$ (peer-to-peer economy) donne la primauté à la valeur d'usage d'un bien plutôt qu'à sa propriété :

Ownership is no longer the be-all-and-end-all it once was, Walker insists. The days of defining yourself by the flash car in your driveway are on the wane. [...] As Walker puts it: "It's experience that people feel most valuable now. Mobility is important because it makes experiences happen, and the ownership of a car is secondary in that." (The Guardian, 2012a)

It is important to highlight the benefits that access provides in contrast to the disadvantages of ownership and sharing. These consist of convenient and cost-effective access to valued resources, flexibility, and freedom from the financial, social, and emotional obligations embedded in ownership and sharing. (HBR, 2015a) 
comme dans sa sphère d'origine qui est l'informatique, le pair à pair appliqué à l'économie s'inscrit comme une alternative voire comme une forme de résistance à une logique propriétaire restrictive, avec une volonté idéologique de se tenir à l'extérieur du marché, dans un système purement coopératif (Bacache-Beauvallet \& Cagé, 2016 : § 5).

Ce rapport nouveau à la possession s'est développé, en partie, sous l'effet de la crise économique de 2008 : des consommateurs ayant perdu de leur pouvoir d'achat se sont tournés vers un système différent qui leur permettait de continuer à consommer sans se priver, en privilégiant les échanges directs entre pairs, sans passer par des institutions gouvernementales ou bancaires.

En conséquence, l'économie du pair à pair est présentée comme un moyen, pour les «citoyens ordinaires" d'accéder à des biens et services qui, dans une logique de marché classique, resteraient hors de portée des consommateurs les moins fortunés :

P2P is a movement that was first embraced by millennials who felt the impact of economic recessions and were in search of an alternative way to work and live. The powerbrokers in the economy often denied them or put items they desired out of reach. Because of this, those who backed this economic movement developed ways to exchange goods and services without a third party. (Forbes, 2017a) sémantique lors de son passage du domaine spécialisé de l'informatique à celui de l'économie. À l'origine, il désignait un système marqué par une coopération libre entre producteurs et consommateurs, associés sans attente de contrepartie monétaire, et où sont reconnus les compétences et les mérites des uns et des autres de façon égalitaire via une reconnaissance entre et/ou par les pairs. On peut citer, comme formes bien connues d'échange et de production peer to peer, le projet d'encyclopédie collective Wikipedia, les logiciels libres et open source comme le programme de messagerie électronique Mozilla Thunderbird, ou encore les Massive Online Open Courses (MOOC), proposés par un nombre croissant d'universités à travers le monde pour faciliter l'échange des savoirs. La collaboration entre pairs offre ainsi à ses adeptes une perspective autre que la maximisation de valeur économique, en les invitant à s'affilier à un projet porteur de sens qui doit contribuer au bien commun.

Dans le champ de l'économie, en revanche, l'appellation de " pair à pair " sert plutôt à nommer des transactions dont les intermédiaires sont engagés dans des relations exclusivement marchandes, dans des systèmes centralisés (Bacache-Beauvallet \& Cagé, 2016 : § 5). Certains réseaux peer-to-peer comme Skype, apparus initialement comme des systèmes d'échange purement coopératifs, ont ainsi introduit un nombre important de services payants, s'éloignant des échanges directs entre particuliers, qui garantissaient à ces derniers un accès libre et universel à des biens matériels ou immatériels (ibid.). C'est donc probablement pour tenir compte du caractère évolutif de la notion de pair à pair que des journalistes privilégient l'emploi d'expressions comme peer-to-peer market phenomenon (BBC, 2013b), monetised peer-to-peer services (The Guardian, 2014a) et peer-topeer transactions (Time, 2016), dès lors que les échanges entre pairs sont marqués par la présence de plateformes commerciales intermédiaires qui tirent profit de la mise en relation des acteurs du marché.

Porteurs de connotations positives, tous les termes que nous avons analysés dans la deuxième partie de cet article permettent aux journalistes de valoriser un système qui, en favorisant l'usage et non la possession, contribue à créer des liens sociaux, à lutter 
contre l'individualisme et l'hyperconsommation et à préserver l'environnement. Conformes aux aspirations de la société civile vers plus de partage et de coopération, ces formes lexicales peuvent être qualifiées d'« économiquement correctes ».

Bien que les premières désignations rencontrées dans les textes soient « orientées vers la recherche du consensus» (Amossy, 2006:30), les suivantes se tournent «vers l'exposition et l'amplification du désaccord»(ibid.). Au sein de la communauté journalistique, la divergence d'opinions se manifeste tout particulièrement dans les commentaires métalinguistiques qui visent l'emploi de sharing economy et de peer-topeer economy. Elle est également perceptible dans les termes et expressions qui dénoncent des aspects plus sombres du modèle socio-économique contemporain.

\section{Les formes linguistiques plus critiques : une prise de position contre « l'économiquement correct »?}

\subsection{Les commentaires métalinguistiques qui visent l'emploi de sharing economy et de peer-to-peer economy}

36 À la lecture des articles, nous avons noté que bon nombre de commentaires métalinguistiques critiquent l'utilisation des termes peer-to-peer economy et sharing economy ${ }^{10}$.

Pour plusieurs auteurs des textes du corpus, la démarche altruiste n'est pas constitutive de tous les modes de production et de consommation dits « collaboratifs ». Si le partage peut être considéré comme un acte communautaire dans la mesure où il relie les individus directement entre eux, crée du lien social et favorise des sentiments de solidarité, il n'est pas nécessairement le but premier de certaines plateformes commerciales en ligne comme Zipcar, qui privilégient la captation de valeur aux échanges directs entre utilisateurs :

The first "sharing economy" organisations allowed members to timeshare things such as cars or power tools, rather than owning one each and leaving it idle most of the time. In their purest form such groups were "peer-to-peer": self-organising, with no central authority. Once a for-profit company is set up to handle the logistics - such as Zipcar - however, the notion of "sharing" is arguably already out of the window. (The Guardian, 2016b)

Dans ces modèles d'affaires, l'échange de biens est souvent remplacé par un système d'accès contrôlé par les entreprises, au moyen de pratiques comme la location, le leasing ${ }^{11}$, la concession, le paiement de droits d'admission, d'adhésion ou d'abonnement qui en définissent l'usage provisoire :

When "sharing" is market-mediated - when a company is an intermediary between consumers who don't know each other - it is no longer sharing at all. Rather, consumers are paying to access someone else's goods or services for a particular period of time. (HBR, 2015a)

De plus, pour bon nombre de consommateurs, l'acte d'achat semble moins guidé par des préoccupations sociales ou environnementales que par la quête de rentabilité et d'efficacité : "it is an economic exchange, and consumers are after utilitarian, rather than social, value » commente un journaliste (HBR, 2015).

Comme l'observe Kalamar (2013), certains dirigeants d'entreprises sont habilement parvenus à masquer la visée strictement mercantile de leurs actions en présentant leurs activités comme tournées vers le partage, l'altruisme et le désintéressement 
financier, ce qui leur a permis d'accroître la popularité de leur structure auprès du grand public. Largement déployée par les partisans du modèle, cette rhétorique, que l'auteur qualifie de "sharewashing", doit inspirer aux membres de la société civile un sentiment de confiance et une volonté de « coopérer de façon spontanée, c'est-à-dire sur la base de valeurs partagées et informelles » (Pauwels, 2015 : § 8).

41 C'est également ce que relève McKean, une lexicographe américaine, dans son analyse $\mathrm{du}$ discours des plateformes commerciales en ligne (The New Yorker, 2015). Selon l'auteure, la mention du partage et/ou des pairs consiste, pour certaines entreprises, à mettre en avant les contributeurs afin de mieux les valoriser et de faciliter leur acceptation des modèles collaboratifs (ibid.). Cette démarche stratégique peut également servir à camoufler un contrôle strict de l'activité professionnelle par les propriétaires de certaines plateformes, ainsi que les conditions d'exercice parfois difficiles des travailleurs :

Framing it as "sharing" or "peers" is a way of trying to keep the focus on the people who provide the services-and off the platforms, which may be very rigid and deterministic as to when, where and how the services are delivered. (The New Yorker, 2015)

42 Tout en dénonçant l'inadéquation des vocables sharing et peer-to-peer, certains commentaires métalinguistiques soulignent les effets néfastes de formes corporatistes d'économie collaborative sur la société. C'est le cas de la formulation ci-dessous, teintée d'ironie, qui fait référence au célèbre roman dystopique de Huxley, Le Meilleur des mondes (Brave New World, 1932) :

The brave new sharing world did a lot of good by eliminating barriers to trade. It removed protectionism and increased competition. It promoted rapid entry into previously regulated professions. It reduced prices for consumers and helped deploy assets more efficiently. But, yes, it also circumvented longstanding welfare protections that previous generations fought hard to secure for workers. (Forbes, 2017b)

43 Ainsi détournée, l'expression permet au journaliste de mettre en évidence une baisse potentielle des standards de protection sociale pour les travailleurs des plateformes numériques, qui sont généralement tenus d'assumer les risques liés à l'exercice de leur activité (investissement, clientèle, risques physiques), tout en étant peu autonomes dans l'organisation de leur activité (processus calibrés, prix fixés par la plateforme et contrôlés à la fois par cette dernière et par les consommateurs).

\subsection{Les termes et expressions critiques}

\subsubsection{Gig economy}

Originaire de la culture musicale américaine, le mot d'argot " gig » est apparu dans les années 1920 pour désigner l'activité des musiciens de jazz, rémunérés au concert ou à la tâche : « a public performance, especially of jazz or popular music » (Macmillan, 2020). Son association à l'économie, à partir de 2009, marque la temporalité, plus courte que par le passé, du travail proposé par les plateformes, ainsi que la pluralité des activités exercées par les travailleurs des plateformes numériques pour en tirer des moyens de subsistance :

I've been using another term to describe these companies: "gig economy". It's not as well-

known as "sharing economy", which means it sounds weird to some ears ("do you mean

Uber only hires musicians?"). But it emphasises the unifying aspect is short-term, tenuous

"gigs" - often more than one juggled at the same time. (The Guardian, 2015b) 

" économie des petits boulots ${ }^{12}$ " un système qui entraîne une flexibilisation du marché
de l'emploi, plus instable et plus imprévisible, et dans lequel le travail indépendant semble plus subi que choisi :

Its members are diverse: immigrant Uber drivers and millennial interns, part-time lecturers and the cleaners and couriers of the "gig economy", the old working class forced into temporary and casual labour. (The Guardian, 2016c)

Martha is part of a burgeoning segment of the workforce loosely known as the gig economy. Approximately 150 million workers in North America and Western Europe have left the relatively stable confines of organizational life sometimes by choice, sometimes not - to work as independent contractors. (HBR, 2018)

\subsubsection{9 economy}

Apparue aux États-Unis en 2015, l'expression 1099 economy fait référence aux formulaires fiscaux délivrés par l'administration fiscale américaine aux citoyens pour la déclaration de leurs revenus d'activité non salariée. Tout comme la forme précédente, elle exprime la temporalité courte des contrats qui sont proposés aux travailleurs de l'économie collaborative.

In the US, "1099 economy" is often used, referring to the American tax code for independent contractors, while in the UK, similar emphasis is placed on "zero-hour contracts": terms of employment which provide no fixed hours and don't even guarantee work will be provided at all. (The Guardian, 2015b)

As I followed my interview schedule around New York [...], the workers I met from the 1099 economy (1099, because the money arrives piecemeal, rather than through W-2 employment) spoke often about making do with limited recourse. (The New Yorker, 2018)

Dans d'autres extraits du corpus, 1099 economy permet aux auteurs d'annoncer un déclin $\mathrm{du}$ salariat au profit de l'emploi indépendant, ainsi qu'un déplacement des risques et des responsabilités correspondant à l'activité professionnelle, qui incombent désormais aux travailleurs :

But there's a reason the gig economy is also known as the 1099 economy, with the number a reference to the tax form issued to independent contractors: workers in such arrangements are not employees of any company, and the onus is on them to run what are essentially their own businesses, even if the business is simply renting a room through Airbnb or providing rides through Lyft or Uber. (The New York Times, 2016)

\subsubsection{Platform capitalism et rentier capitalism}

Inventées par des spécialistes de l'économie avant d'être reprises dans le discours médiatique, les expressions platform capitalism (" capitalisme de plateforme ») et rentier capitalism (" capitalisme de rente ${ }^{13} »$ ) mettent l'accent non seulement sur la création de valeur par des plateformes commerciales en ligne, mais aussi sur son partage inégalitaire entre demandeurs et offreurs de travail.

Comme l'explique Standing, un économiste britannique dont les propos sont rapportés dans le quotidien The Guardian et que nous reproduisons ci-dessous, certaines de ces plateformes, qui se réclamaient au départ de modèles collaboratifs, s'inscrivent 
en réalité dans un rapport où l'exploitation d'une main-d'œuvre flexible et peu coûteuse constitue une source de "rente» pour leurs propriétaires, lesquels s'enrichissent principalement par leur statut d'intermédiaire et par la collecte de données des utilisateurs :

Most platforms are parasitic: feeding off existing social and economic relations. They don't produce anything on their own - they only rearrange bits and pieces developed by someone else. Given the enormous - and mostly untaxed - profits made by such corporations, the world of "platform capitalism", for all its heady rhetoric, is not so different from its predecessor. The only thing that's change is who pockets the money. (The Guardian, 2015a) What matters is that technologies are destroying the way our income and earnings have been distributed. A new "rental wedge" has been created - between profits, which are growing, and ever more concentrated, and wages, which are falling and ever more uncertain. [...] Unlike in the past, power today lies not with corporations that control the means of production, but with those that control the "technological apparatus". (The Guardian, 2016c)

51 Pour l'auteur, l'essor du nouveau type d'économie entraîne une modification des statuts d'emploi et des conditions d'exercice, qui deviennent plus précaires et plus instables que par le passé : "Work is no longer the road to riches, or even the way out of poverty. There may be more work, but it pays less. » (The Guardian, 2016c) Il cherche ainsi à dénoncer le développement d'un capitalisme rentier qui n'assume plus les responsabilités traditionnelles de l'employeur et qui invite les travailleurs à valoriser leur propre travail sur le marché des services : «The kind of platform capitalism that seeks to turn everyone into a precarious entrepreneur. » (The Guardian, 2016a)

52 Faisant écho à toutes les désignations critiques présentées dans la troisième partie de cet article (gig economy, 1099 economy, etc.), les expressions qui servent à nommer les travailleurs de l'économie collaborative sous des formes variées suggèrent une relative indétermination quant aux conditions de travail, au statut et à l'identité de la nouvelle main d'œuvre: "always-on self-entrepreneurs who must think like brands» (The Financial Times, 2013), "legions of network co-ordinated serfs" (The Guardian, 2014b), "workers on tap» (The Economist, 2015), "the precariat» (The Guardian, 2016c), "employeeserfs » (Bloomberg, 2017), « consultants, independent contractors, freelancers, side-giggers, and on-demand workers » $(H B R, 2019)$.

\subsubsection{Uberization}

53 Un autre terme dont nous avons noté la présence au sein du corpus est celui d'uberization (anglais américain) ou uberisation (anglais britannique), formé à partir du nom d'une multinationale californienne de création récente et à forte croissance (start-up), ce qui donne à la notion une apparence de modernité.

54 Sur le plan théorique, ce terme est présenté positivement dans la mesure où ses définitions, tant en anglais qu'en français, mettent l'accent sur le potentiel de transformation des secteurs économiques traditionnels (santé, fret, banque, etc.), à la suite de l'arrivée d'un nouvel entrant sur les marchés, qui propose aux consommateurs un choix élargi de biens, disponibles à moindre coût :

Uberisation: the act or process of changing the market for a service by introducing a different way of buying or using it, especially using mobile technology. (Cambridge Dictionary, 2020)

Ubérisation: remise en cause du modèle économique d'une entreprise ou d'un secteur d'activité par l'arrivée d'un nouvel acteur proposant les mêmes services à 
des prix moindres, effectués par des indépendants plutôt que des salariés, le plus

souvent via des plateformes de réservation sur Internet. (Larousse, 2018) termes et des expressions qui servent à désigner l'économie collaborative dans la presse anglophone. Ce phénomène tient probablement à la diversité des modèles collaboratifs existants, et à la volonté de leurs dirigeants d'intégrer, à des degrés différents, des critères de responsabilité économique, sociale et environnementale.

Nous avons ensuite eu l'occasion d'observer l'évolution de quelques-unes de ces formes et de voir de quelle façon elles contribuent à façonner, ou à modifier, les représentations collectives du réel socio-économique.

Les premières désignations choisies par les journalistes, de 2012 à 2015, véhiculent des représentations largement positives où le nouveau type d'économie ouvre la voie à une nouvelle "ère du partage ", rendue possible par l'essor des nouvelles technologies. Leur présence nous paraît refléter les attentes et les aspirations des citoyens, désireux de vivre en conformité avec des valeurs d'échange et de solidarité, et d'agir pour la préservation et la gestion des biens communs.

En revanche, de 2015 à 2019, ces dénominations « économiquement correctes » sont reprises et accompagnées de commentaires métalinguistiques à visée sarcastique et de termes et expressions plus directs. Vraisemblablement, le but de cette rhétorique « n'est pas tant de dénoncer l'autre qui nomme inadéquatement que de se présenter comme un traducteur, un médiateur, une instance qui explicite le propos d'autrui » (Krieg-Planque, 2004:34). Ayant constaté la présence de modèles d'affaires dans lesquels le partage n'occupe qu'une place limitée, certains auteurs, en effet, cherchent à désambiguïser et à préciser le sens de la notion d'économie collaborative en privilégiant l'emploi d'expressions alternatives comme monetised peer-to-peer services. 
61 recours à ces formes lexicales montre également que les journalistes sont soucieux de préserver une forme d'autonomie par rapport au langage économique dominant, notamment en questionnant l'impact du nouveau type d'économie sur le marché du travail, marqué, certes, par une plus grande collaboration entre acteurs, mais aussi par une flexibilisation des statuts professionnels et des conditions d'exercice.

\section{BIBLIOGRAPHIE}

\section{Références secondaires}

ALGAR Ray (2007), «Collaborative Consumption », Leisure Reports, avril 2007, 16-17.

Amossy Ruth (2006), L'argumentation dans le discours ( $2^{\mathrm{e}}$ éd.), Paris : Armand Colin.

BACACHE-BeAuvallet Maya \& CAGE Julia (2016), « Pair à Pair : les véritables enjeux économiques », Revue d'économie industrielle, 155, <https://doi.org/10.4000/rei.6391>.

BENEDETTO Caroline (2019a), « L'anglais du marketing et ses innovations lexicales : une étude de la presse professionnelle américaine ", Neologica : revue internationale de néologie, 13, La néologie à l'ère de l'informatique et de la révolution numérique, 163-180.

BENEDETTO Caroline (2019b), « Une approche de la culture professionnelle des soignants à travers les films de recrutement ", ASp : la revue du Groupe d'étude et de recherche en anglais de spécialité (GÉRAS), 75, 25-47.

BOSTMAn Rachel \& Rogers Roo (2010), What's Mine is Yours: The Rise of Collaborative Consumption, New York : HarperCollins.

CAMBRIDGe Dictionary (2020), « Uberisation », en ligne sur <https://dictionary.cambridge.org/fr/ dictionnaire/anglais/uberization? $q=u b e r i s a t i o n>(16$ décembre 2020).

CENTRE NATIONAL De Ressources teXtuelles et leXicales (2020), « Leasing », en ligne sur $<$ www.cnrtl.fr/definition/leasing> (16 décembre 2020).

COLLINS Dictionary (2020), « Gig Economy », en ligne sur <www.collinsdictionary.com/dictionary/ english/gig-economy> (16 décembre 2020).

ETYMONLINE (2020), Online Etymology Dictionary, en ligne sur <www.etymonline.com> (16 décembre 2020)

FELSON Marcus \& SPAETH Joe L. (1978), « Community Structure and Collaborative Consumption: A Routine Activity Approach », American Behavioral Scientist, 21, 614-624.

GANSKY Lisa (2010), The Mesh: Why the Future of Business Is Sharing, New York : Penguin.

GöRöG Georgina (2018), « The Definitions of Sharing Economy: A Systematic Literature Review », Management, 13(2), 175-189. 
HENNI Ahmed (2012), Le capitalisme de rente. De la société du capitalisme industriel à la société des rentiers, Paris : L'Harmattan.

HuXLEY Aldous (1932), Brave New World, New York : Harper Brothers.

KalAmar Anthony (2013), « Sharewashing Is the New Greenwashing », OpEdNews, 13 mai.

KRIEG-PLANQUE Alice (2004), « Souligner l'euphémisme : opération savante ou acte d'engagement? Analyse du "jugement d'euphémisation" dans le discours politique », Semen, 17, <https://doi.org/ 10.4000/semen.2351>.

LAROUSSE (2017), Le Petit Larousse illustré, Paris : Larousse.

MACMILlAn DictionaRy (2017), « Digital Economy », en ligne sur <www.macmillandictionary.com/ dictionary/british/the-digital-economy> (16 décembre 2020).

MACMILlan Dictionary (2020), “Gig”, en ligne sur <www.macmillandictionary.com/dictionary/ british/gig_1>.

OQLF - OFFICE QUÉBÉCOIS DE LA LANGUE FRANÇAISE (2016), « Économie du partage », en ligne sur $<$ http://gdt.oqlf.gouv.qc.ca/ficheOqlf.aspx?Id_Fiche=26532944> (16 décembre 2020).

PAUWELS Marie-Christine (2015), « La consommation collaborative aux États-Unis », Revue LISA / LISA e-journal, 13(2), <https://doi.org/10.4000/lisa.8455>.

The People Who Share (2010), « Page d'accueil du site », en ligne sur $<$ www.thepeoplewhoshare.com> (16 décembre 2020).

ShAREABLE (2020), « Page d'accueil du site », en ligne sur <www.shareable.net> (16 décembre 2020). SRNICEK Nick (2018), Le capitalisme de plateforme. L'hégémonie de l'économie numérique, Montréal : Lux.

\section{Corpus}

Seules les références citées dans l'article figurent dans cette section ${ }^{15}$. Elles sont classées chronologiquement : l'année de publication apparaît à côté de chaque référence. Lorsque plusieurs articles de presse ont été publiés la même année, nous avons ajouté une lettre à côté de leur date de publication.

\section{2}

BBC (2012), « TEDGlobal: Sharing Sites Revive the Barter Economy », 29 juin.

FoRBES (2012), « Airbnb Had \$56 Million Impact On San Francisco: Study », 9 novembre.

THE GUARDIAN (2012a), « Why Sharing Makes Sense in an Over-Consuming World », 12 janvier.

THE GUARDIAN (2012b), « Teaching the World to Share », 16 juillet.

THE GUARDIAN (2012c). « World Sharing Day Celebrates Collaborative Consumption », 14 novembre.

THE NEW YoRK Times (2012), « Commander of the Apps, Except the One for Guilt », 22 septembre. 


\section{3}

BBC (2013a), « Renting and Sharing: The Business of the Future », 31 janvier.

BBC (2013b), « Will the Peer-to-Peer Market Phenomenon Survive? », 17 septembre.

THE FinANCIAL Times (2013), « The ‘Sharing Economy' Undermines Workers' Rights », 14 octobre.

THE GUARDIAN (2013), « The Sharing Economy: A Whole New Way of Living », 4 août.

\section{4}

THE ECONOMIST (2014), « Workers on Tap », 30 décembre.

THE GUARDIAN (2014a), « Sharing Economies Are Here to Stay », 7 mai.

THE GuARDiAn (2014b), « Meet Tech's New Concierge Economy, Where Serfs Deliver Stuff to Rich Folk », 27 décembre.

THE NEW YoRK Times (2014), « The Push to Regulate the Sharing Economy », 29 avril.

\section{5}

The Financial Times (2015), « Business Books Review: 'Peers Inc' by Robin Chase », 10 juin.

THE GUARDIAN (2015a), « Where Uber and Amazon Rule: Welcome to the World of the Platform », 7 juin.

THE GUARDIAN (2015b), « Why the Term ‘Sharing Economy’ Needs to Die », 5 octobre.

HBR (2015a), « The Sharing Economy Isn't about Sharing at All », 28 janvier.

HBR (2015b), « Who Benefits from the Peer-to-Peer Economy?», 28 juillet.

TIME (2015), « The On-demand Economy Takes Workers for a Ride », 23 juillet.

THE NeW Yorker (2015), « Twisting Words to Make ‘Sharing’ Apps Seem Selfless », 8 août.

\section{6}

THE GuARDIAN (2016a), « Silicon Valley Talks a Good Game on ‘Basic Income’, but Its Words Are Empty ", 28 février.

THE GUARDIAN (2016b), « What's Yours Is Mine: Against the Sharing Economy by Tom Slee Review - The Problem with Airbnb and Uber », 2 avril.

THE GUARDIAN (2016c), « The Corruption of Capitalism by Guy Standing Review - Work Matters Less than What You Own », 26 octobre.

THE NEW YoRK Times (2016), « Tax Tips for Those Who Make Money in the Gig Economy », 5 mars. Time (2016), « The Way We Work. A New Poll Reveals the Size of the Peer-to-Peer Revolution », 18 janvier. 


\section{7}

BLOOMBERG (2017), « Why 'Sharing Economy' Comes Wrapped in Faith and Fear: QuickTake », 13 septembre.

Forbes (2017a), « How Gen Z Will Affect the Future of the Peer-to-Peer Economy », 29 août.

FoRBES (2017b), « Are Uber Drivers Employees? The Answer Will Shape the Sharing Economy », 15 novembre.

THE GUARDIAN (2017), « John McDonnell: We Must Stop ‘Uberisation’ of the Workplace », 17 novembre.

\section{8 et 2019}

HBR (2018), « Thriving in the Gig Economy », mars-avril.

HBR (2019), « Universities Should Be Preparing Students for the Gig Economy », 3 octobre.

\section{Sources en français}

LE MONDE (2016), « L'ubérisation trahit la promesse de l'économie du partage », 13 octobre.

LE MONDE (2017a), « Au Royaume-Uni, des propositions controversées pour améliorer le statut des travailleurs précaires », 11 juillet.

LE MonDE (2017b), « TaskRabbit, pionnier de l'économie des petits boulots, racheté par Ikea », 30 septembre.

LE MoNDE (2018), « Des ambulanciers mobilisés contre l'ubérisation de leur profession »,

7 novembre.

LE MONDE (2019), « Les plates-formes du numérique n'ont pas pu s'opposer au mouvement de fond actuel pour une meilleure redistribution », 17 septembre.

LES ÉcHOS (2017), « “Petits boulots” et grandes entreprises », 12 janvier.

LES ÉcHOS (2019), « Comment éviter l'ubérisation de la santé ? », 17 octobre.

\section{NOTES}

1. La première référence explicite à la notion d'économie collaborative est la forme collaborative consumption, apparue en 1978 pour désigner la pratique du covoiturage, dans un article publié par les sociologues américains Felson et Spaeth. Elle fut réintroduite une trentaine d'années plus tard, en 2007, sous la plume de Algar, consultant en finance et en marketing, dans un article de la revue spécialisée Leisure Reports, avant de se diffuser plus largement dans le discours public sur l'économie.

2. Nous appelons "terme" tout mot ou groupe de mots dont l'utilisation est attestée dans la langue, et dont le sens figure dans les dictionnaires, généraux ou de spécialité. Les autres formes lexicales qui ne correspondent pas à ces critères ont été nommées " expressions ».

3. Leur sens et leurs premières attestations ont été vérifiés dans un dictionnaire étymologique en ligne (etymonline.com) et dans des dictionnaires de langue anglaise. 
4. «An economy which is largely based on computers, the Internet and digital technologies " (Macmillan, 2017). Au moment de la rédaction de cet article, le terme sharing economy affichait plus de 6 millions d'occurrences sur le moteur de recherche Google, contre 3590000 pour gig economy, 425000 pour on-demand economy et 322000 pour collaborative economy.

5. La recherche a porté sur l'ensemble des pays, car le filtre de recherches de l'outil en ligne Google Trends ne permet pas à ses utilisateurs de sélectionner, de façon simultanée, une sélection de pays, comme ceux de l'aire anglophone.

6. Bien que le terme "économie du partage » existe officiellement dans la langue française (OQLF, 2016), il demeure nettement moins présent dans le discours public que le terme « économie collaborative ».

7. Notre traduction.

8. Plusieurs variantes de cette expression ont été relevées au sein du corpus, allant de peer-to-peer marketplace à peer-to-peer lending schemes, en passant par peer-to-peer energy generation et peer-topeer holiday lodging market.

9. Notre traduction.

10. Ce dernier est décrit, entre autres, comme « one of the most rhetorically abused virtues of the age » (The Guardian, 2016b).

11. Leasing: emprunté à l'anglais, ce terme désigne la location-vente de matériel ou de bien d'équipement qui est assortie d'une option d'achat au terme d'une période déterminée (Centre national de ressources textuelles et lexicales, 2020).

12. Ces traductions sont celles proposées dans Le Monde (2017a, 2017b, 2019) et Les Échos (2017), par exemple.

13. Voir, par exemple, les ouvrages suivants : Le capitalisme de plateforme. L'hégémonie de l'économie numérique (Srnicek, 2018) et Le capitalisme de rente. De la société du capitalisme industriel à la société des rentiers (Henni, 2012).

14. Ce terme désigne le «fait d'adopter un modèle d'entreprise dans lequel une organisation, au moyen d'une plateforme web, agit à titre d'intermédiaire entre particuliers plutôt qu'en tant que fournisseur de biens et de services, dans un secteur d'activité où une telle pratique est innovatrice » (Office québécois de la langue française, 2017).

15. Le corpus dans son intégralité peut être transmis par l'auteure sur simple demande écrite.

\section{RÉSUMÉS}

L'objet de cet article est d'étudier quelques-uns des termes et expressions qui servent à désigner l'économie collaborative dans la presse anglophone, à partir d'un corpus d'articles publiés entre 2012 et 2019. De quelle façon ces formes lexicales contribuent-elles à façonner ou à modifier les représentations collectives du réel socio-économique ? Cette étude montre que la période 2012-2015 est marquée par l'emploi de termes qui soulignent les aspects positifs du nouveau type d'économie. Conformes aux aspirations de la société civile vers plus de partage et de coopération, ces vocables sont qualifiés d'«économiquement corrects». En revanche, l'émergence de formes linguistiques plus critiques, de 2015 à 2019, permet aux journalistes de prendre position sur le sujet, non seulement en remettant en cause le choix des termes précédents, mais aussi en évoquant des aspects plus sombres du modèle économique tels que le déclin du salariat au profit de la multiplication du travail à la tâche. 
This contribution aims to analyze some of the terms and expressions that refer to the sharing economy in a body of articles published in the English-speaking press between 2012 and 2019. In what ways do these lexical forms contribute to the shaping or to the modification of the public representation of the economic situation? Between 2012 and 2015, several terms are used to highlight the positive aspects of the sharing economy. As these new words correspond to public demand for more sharing and cooperation, they are qualified as "economically correct". In contrast, between 2015 and 2019, words and expressions became more critical in nature. Journalists not only denounce the use of the positive words, but they also describe some unintended consequences of the economic model, such as the replacement of stable work by short-term and part-term employment.

\section{INDEX}

Mots-clés : analyse du discours, économie collaborative, économiquement correct, presse anglophone, terminologie

Keywords : discourse analysis, sharing economy, economically correct, English-speaking press, terminology

\section{AUTEUR}

\section{CAROLINE BENEDETTO}

Université Paris-Est Créteil (UPEC).

Caroline Benedetto enseigne l'anglais des affaires et la communication professionnelle à l'École supérieure d'ingénieurs de Paris-Est Créteil (UPEC). Ses recherches portent sur la culture des milieux professionnels anglophones, l'analyse du discours, la terminologie et la lexicologie. caroline.benedetto2@gmail.com 